\title{
Forestry Dialogue Forestier
}

\section{INFORMATION FOR PARLIAMENTARIANS — INFORMATION POUR LES PARLEMENTAIRES}

\section{\#27 JANUARY 1990}

\section{FORESTS AND CLIMATE CHANGE}

Climate change is not a new phenomenon. Although the world's climate has always warmed and cooled during different epochs due to natural causes, the average temperature of the earth's surface has remained remarkably constant over the past 100000 years. More recently, however, human activities associated with production and consumption activities have confounded these natural processes, and mankind's actions have now become a significant factor in influencing present and future climatic conditions.

The most significant human impact on climate results from the increasing emissions of gases (particularly carbon dioxide, nitrous oxide, methane, chlorofluorocarbons and ozone) into the atmosphere. Other impacts include changing land use (e.g. conversion of tropical and temperate forests to savannah, and agricultural and grass lands to deserts), urban heat, jet condensation trails, smoke and dust. These impacts have resulted in a global warming of about $0.6^{\circ} \mathrm{C}$ over the past century, and it is predicted that a further rise of 1 to $4.5^{\circ} \mathrm{C}$ will take place by the 2030's unless human impacts are greatly reduced immediately. High latitudes in both hemispheres will experience the greatest warming, and the amount of warming will be greatest in the winter months. Canada may thus bear the brunt of the impact of climate change in North America.

\section{Impact on Trees and Forests}

1. Canada's tree line will gradually migrate about $100 \mathrm{~km}$ northwards, for every celcius degree of warming. This will result in a northward relocation of the zone of maximum growth of a given tree species.

2. Tree growth will be enhanced in areas where temperature is now a limiting factor.

3. It is likely that new species, varieties and forms will evolve as a result of climatic change, species migration and exposure to new habitats.

4. The anticipated increase in temperature is likely to increase the intensity and frequency of forest fires.

5. The warming will effect the activity, abundance and distribution of many insects and diseases. A warmer climate is likely to extend the distribution range of some insects and diseases to higher altitudes.

6. Reduced snow cover and warmer winters will require adjustments in forest harvesting operations especially when heavy machinery and equipment are used.

7. Changes in the growth and composition of forests and associated ground vegetation will likely influence wildlife populations.

Forests are the basis for economic activities of many communities and changes in the forest resource base would have far-reaching economic, social and environmental consequences. Biological and social research studies are required to enable society to understand, cope with and adapt to potential changes in our forest resources.

(Adapted from a paper by J.S. Maini, Asst. Deputy Min., Forestry Canada.)

\section{\#27 JANVIER 1990}

\section{LES FORÊTS ET LES CHANGEMENTS CLIMATIQUES}

Les changements climatiques ne sont pas un phénomène nouveau. Même si le climat du globe s'est réchauffé ou refroidi au cours de différentes époques par suite de causes naturelles, la température moyenne de la surface de la Terre est demeurée remarquablement constante au cours des derniers 100000 ans. Plus récemment, toutefois, les activités humaines associées aux activités de production et de consommation ont perturbé ces processus naturels, et les activités du genre humain sont maintenant devenues un facteur significatif influençant les conditions climatiques actuelles et futures.

L'impact humain le plus significatif sur le climat est constitué par les émissions toujours croissantes de gaz (notamment de l'anhydride carbonique, des oxides nitreux, du méthane, des chlorofluorocarbones et de l'ozone) dans l'atmosphère. Les autres impacts comprennent la modification de l'utilisation du territoire (par ex. la conversion des forêts tropicales et tempérées en savanes, et des prairies et des terres agricoles en déserts), la chaleur des zones urbaines, les trainées des gaz d'échappement des réactés, les fumées et les poussières. Ces impacts ont provoqué un réchauffement global de près de 0,6 degré Celsius, par rapport au siècle dernier, et on prédit une autre hausse de 1 à 4,5 degrés Celsius d'ici l'an 2030, à moins que les impacts humains soient considérablement réduits dès maintenant. Les hautes latitudes des deux hémishpères enregistreront les plus forts réchauffements, et le niveau de réchauffement sera le plus élevé au cours des mois d'hiver. Le Canada pourra avoir à supporter le choc du changement climatique en Amérique du Nord.

\section{Impact sur les Arbres et les Forets}

1. La limite des arbres au Canada se déplacera graduellement de $100 \mathrm{~km}$ vers le nord, pour chaque degré Celsius de réchauffement. II en résultera une relocalisation plus nordique de la zone de croissance d'une espèce donnée d'arbres.

2. La croissance des arbres sera favorisée dans les régions où la température est présentement un facteur limitatif.

3. II est fort probable que de nouvelles espèces, variétés et formes se développeront suite à ces changements climatiques, à la migration d'espèces et à l'exposition de nouveaux habitats.

4. L'accroissement prévu de la température pourra accroître l'intensité et la fréquence des feux de forêts.

5. Le réchauffement affectera l'activité, l'abondance et la distribution de plusieurs insectes et maladies. Un climat plus chaud favorisera probablement l'accroissement de l'aire de distribution de certains insectes et maladies vers des altitudes plus élevées.

6. La réduction de la couche de neige et des hivers plus doux provoqueront des ajustements dans les opérations de récolte forestière notamment lorsque que de la machinerie lourde est utilisée.

7. Les changements dans la croissance et la composition des forêts et de la végétation terrestre qui lui est associée influencera sensiblement les populations d'animaux sauvages.

Les forêts sont à la base des activités économiques de plusieurs communautés et des changements dans les ressources forestières auraient des conséquences importantes au point de vue économique, social et environnemental. Des études en recherche biologique et sociale sont requises pour permettre à la société de comprendre, de faire face et de s'adapter aux changements possibles dans nos ressources forestières.

(Adapté d'un exposé de J.S. Maini, sous-ministre adjoint, Forêts Canada.) 